\title{
THE PROBLEM OF DA'WAH AND ISLAMIZATION IN THE MENTAWAI ISLANDS
}

\author{
Nelmaya \\ Institut Agama Islam Negeri (LAIN) Bukittinggi,nelmaya96@,gmail.com
}

Deswalantri

Institut Agama Islam Negeri Bukittinggi (IAIN)Bukittinggi, deswalantri@gmail.com

\section{(c) (1) (2)}

(C)2021 by the authors. Submitted for possible open access publication under the terms and conditions of the Creative Commons Attribution-ShareAlike 4.0 International License (CC-BY-SA) license (https://creativecommons.org/licenses/by-sa/4.0/) doi) DOI: http://dx.doi.org/10.30983/fuaduna.v5i1.4260

\begin{abstract}
Islamization in Mentawai islands is amidst the majority of non-Muslim Protestant Christians and Catholic Christians. Not to mention the local beliefs held by the Mentawai people who are against Islam. The characteristics of the localities of the Mentawai people who are friendly, kind, and highly appreciative of guests are one of the reasons for Islamization in Mentawai. This research is a research library with a qualitative analysis approach - the data collection work through observation and interviews with preachers concerned with Islamization in the Mentawai. Data analysis techniques use data analysis techniques Miles and Huberman, data reduction, presentation, and conclusions. The process of accepting Islam in Mentawai was peaceful, but due to a lack of guidance, the Mentawai people became apostates again. The Mentawai people convert to Islam by negotiating, such as education, marriage, self-sufficiency, and poverty. Some Mentawi people have started to study tauhid, and many Muslim women have veiled a lot. However, there are still some who choose pigs, done in secret. The government urgently needs to pay attention to Islamization in the Mentawai.
\end{abstract}

Keywords: Islamization, Da’wah; Mentawai Islands.

\begin{abstract}
Abstrak
Islamisasi di Mentawai terjadi di tengah-tengah mayoritas nonmuslim, dimana lebih dominan masyarakat beragama Kristen Protestan dan Kristen Katolik. Belum lagi kepercayaan lokal yang dianut oleh masyarakat Mentawai yang bertentang dengan agama Islam. Karakteristik lokalitas masyarakat Mentawai yang ramah, baik dan sangat menghargai tamu menjadi salah satu alasan terjadinya Islamisasi di Mentawai. Penelitian ini merupakan kualitatif analisis. Data dikumpulkan melalui observasi dan wawancara dengan pendakwah yang peduli dengan Islamisasi di Mentawai. Untuk teknik analisis data menggunakan teknik analisis data Miles dan Huberman, yang terdiri dari reduksi data, penyajian dan kesimpulan. Hasil penelitian ini menunjukkan bahwa proses Islamisasi yang terjadi di Mentawai berjalan damai, tetapi karena kurangnya pembinaan masyarakat Mentawai kembali menjadi murtad. Masyarakat Mentawai masuk Islam dengan melakukan negosiasi, seperti pendidikan, perkawinan, adanya kesadaran diri sendiri dan karena faktor kemiskinan. Sebagian masyarakat Mentawai sudah mulai belajar taubid dan perempuan Muslim telah banyak berjilbab. Walaupun masih ada yang memelihara babi, tapi dilakukan secara sembunyi-sembunyi. Sangat diperlukan kepedulian dari pemerintah untuk memperhatikan Islamisasi di Mentawai.
\end{abstract}

Kata Kunci: Islamisasi; Dakwah; Kepulauan Mentawai. 


\section{INTRODUCTION}

The Mentawai Islands are one of the regencies located in West Sumatra Province. Mentawai district was formed based on the Law of the Republic of Indonesia No. 49 of 1999. ${ }^{1}$ There are 4 main inhabited island groups in the Mentawai district, namely Siberut Island, Sipora Island, North Pagai Island, and South Pagai Island. In addition, several other small islands are inhabited, but some are planted with coconut trees.

The Mentawai people believe that everything that has a name has a soul or spirit, just like humans, animals, plants, everything has a spirit. Spirit is a kind of the spiritual equivalent of everything that exists and is an individual being that can detach itself from the "gross" body and can roam independently. This fact doesn't give a bad description. ${ }^{2}$

Culturally, socially and linguistically, the indigenous Mentawai people are different from the Minangkabau people as the dominant population of West Sumatra. Among the indigenous people of the Mentawai Islands still live in very traditional forests, and some are not fully clothed. The Mentawai Islands are known as Bumi Sikerei, which are dominated by nonMuslims. The religion followed by the Mentawai population is very diverse. Half of them are animists, then some are Christian, and some are Islam. Islam is the earliest religion to enter the Mentawai before Catholic Christianity and Protestant Christianity. ${ }^{3}$

The lack of guidance for converts in Mentawai makes it easy for them to change religions. In this case, intensive da'wah is needed so that Mentawai converts do not easily leave Islam. Amid the power of local religion, the official religion also experienced struggles, so that the indigenous people became a bone of

1 “UU RI No. 49," 1999.

2 Rudito Bambang, "Masyarakat Dan Kebudayaan Suku Bangsa Mentawai," Fisip Universitas Andalas, 1999.

3 Buya Mas'ud Abidin, "Pendakwak Di Mentawai, Wawancara Pribadi," n.d. contention for the official religion, until three religions dominated, namely, Catholic Christianity, Protestant Christianity, and Islam. It is fascinating to observe the competitiveness of the three religions to develop with each other and not clash with each other even with the locality. Catholic and Protestant Christianity can coexist and be accepted by the Mentawai locality.

The process of Islamization that occurs also has implications for the local culture so that Islam can become part of the Mentawai community. Acceptance of locality cannot be separated from negotiations constructed in the spread of Islam so that Islam becomes one of the religions amid the existing majority. Acceptance of Islam amid society and the negotiations that occur so that its arrival does not become one of the new things that are deadly and separate. These negotiations are usually assisted by peaceful approaches, not necessarily destroying old conditions or localities, but how locality can become a media base to assist in the Islamization process. This condition is the same as what Wali Songo did on the island of Java in spreading Islam by building a process of change that is friendly to the locality. ${ }^{4}$

In the context of negotiations, the role is that the Mentawai people can accept Islam by negotiating so that there is no intolerance, disharmony, and religious conflict in the process of spreading Islamization. The process of Islamization that has taken place in the Mentawai so far has been going on peacefully. No negotiations have been undertaken except in carrying out the teachings of Islam. This condition appear as the appeal in the Qur'an Surah Al-Baqarah verse 208 as follows: “O you who believe, enter into Islam as a whole, and do not follow the steps of the devil. Verily, Satan is a real enemy to you." (Al-Baqarah, verse: 208). From the verse above, it can be concluded that the problems of Islamization in Mentawai and

4 Azyumardi Azra, "Islamisasi Jawa," Studia Islamika 20, no. 1 (2013). 
locality influence each other. For this reason, negotiations need to be carried out so that there are no clashes in the process of Islamization in Mentawai.

The research method used in this study is qualitative analysis, with data collection techniques through observation and interviews. For the selection of informants using informants, the perpetrators in the study were converts to the Mentawai Islands, while the observer informants were clerics who carried out da'wah to the Mentawai Islands. While the data analysis technique used is the data analysis technique of Miles and Huberman. ${ }^{5}$

\section{ISLAMIZATION IN MENTAWAI}

The entry of Islam in the Mentawai has various opinions about this, although there is no definite data when the peripheral land traders started trading to the Mentawai but were the ones who developed the Islamic religion casually. ${ }^{6}$ Some people who heard the story by word of mouth thought that Islam had entered the Mentawai long ago, even earlier than other religions, when Bugis and Minangkabau traders came there selling cloth, tobacco, and tobacco machetes, and salt. Long before the Dutch government, even before the VOC entered this area, traders from the outskirts of West Sumatra who were Muslim had traded with the Mentawai people to buy palm leaves, rattan, and others by bartering.ng.

Da'wah in Mentawai has been started since 1950. The first da'wah was driven by Moh. Hatta (Vice President of the Republic of Indonesia). Moh Hatta built a country called God's blessing in Sikakap, but at this time it is neglected due to lack of guidance. Da'wah in 1969 was again carried out in Mentawai, by

${ }^{5}$ Sugiyono Sugiyono, Metode Penelitian Kuantitatif Dan Kualitatif Dan R\&D, 2010.

6 Mochtar Naim, "Kehidupan Agama Di Mentawai" dalam Majalah Bulanan Mimbar Ulama, No. 8 Tahun I Februari" 8 (1977): 35 Dalam; Maskota Delfi, "Sipuisilam Dalam Selimut Arat Sabulungan Penganut Islam Mentawai Di Siberut," Al-Ulum 12, no. 1 (2012): 1-34. sending Dai, one of whom was Ust Usman Marlen Misban Malin, who served to preach in remote areas. ${ }^{7}$

The developments and changes in the Mentawai community cannot be separated from the interaction pattern, whether carried out between local ethnic groups or with outsiders they know. Interaction with outside communities frequently occurs in Mentawai because it is located in a coastal or coastal area. It is in line with the historical record of the entry of Islam in Mentawai. It begins with the entry from the coastal area of Samudra Pasai in the 13th century, ${ }^{8}$ even though this has pros and cons.

Mentawai, as an archipelago, shows that the closest it is to the coast, the more it has developed compared to inland areas. Even though Mentawai is included in the Archipelago, not all Mentawai areas are included in the spread of Islam. The condition can be seen at present that certain areas in the Mentawai Islands are not the dominant Muslim majority in West Sumatra. The latest data shows that Muslims in the Mentawai Islands is the third population for Protestant and Catholic Christians. The number of data can be seen in Table 1 below':

Table 1. Mentawai Community Based on Their Religion

\begin{tabular}{|c|c|c|}
\hline No & Agama & Persentase \\
\hline 1. & Christian & $79,94 \%$ \\
\hline 2. & Catholic & $49,00 \%$ \\
\hline 3. & Moslem & $19,56 \%$ \\
\hline 4. & Confucianism & $0.01 \%$ \\
\hline 5. & others & $0,49 \%$ \\
\hline
\end{tabular}

Source: BPS Kepulauan Mentawai Tabun 2020

7 Silvia Devi, "Adaptasi Masyarakat Di Tuapejat Kabupaten Kepulauan Mentawai Provinsi Sumatera Barat," Jurnal Penelitian Sejarah Dan Budaya 3, no. 2 (2017): 871-893.

8 Achmad Syafrizal, "Sejarah Islam Nusantara," Islamuna: Jurnal Studi Islam 2, no. 2 (2015): 235-253.

9 "Badan Pusat Statistik Kepulauan Mentawai," 2020. 
There are $19.56 \%$ of the Mentawai people are Muslim. Initially, Islam entered the Mentawai. Some say it was through the interaction of traders who stopped in the Mentawai. These trade contacts came from Bengkulu, and some said they were from Pariaman. The more convincing the role of traders in the spread of Islam. Islam entered the Mentawai long before other religions such as Buddhism, Christianity, and Hinduism. Islam is the earliest religion to enter the Mentawai Islands because one North Pagai embraced Islam for five generations.

Before the Islamization process, the Mentawai people adhered to a belief called arat sabulungan, namely the belief in leaves, trees, trees, and roots with supernatural powers used to ward off evil spirits. The Mentawai people are very well known for their religious system (Belief) by worshiping supernatural powers and ancestral spirits (animism). Over time, the government banned this belief by issuing a decree on the Soekarno government, which essentially ordered the Mentawai people to leave Arat Sabulungan and be told to choose one of the religions recognized by the government. However, these efforts did not immediately produce results. This condition was followed by various tactics and strategies carried out by the government so that the Mentawai people were overwhelmed to maintain their consistency and slowly began to leave their beliefs and customs to embrace new beliefs, which inevitably must be accepted.

The reason for the prohibition of arat sabulungan in the context of development and modern civilization, the government and missionaries is a form of primitive tribal religious system that once existed in the Mentawai, it is not wrong to be removed from the life of the Mentawai people ${ }^{10}$. The majority of the Mentawai people are Catholic, Protestant and Muslim Christians, but some Mentawai people still hold fast to their religion, called arat sabulungan.

${ }^{10}$ Ika Rosyani, "Kehidupan Arat Sabulungan Dalam Masyarakat Tradisional Mentawai" (Diss. Universitas Pendidikan Indonesia, 2013).
Some of the Mentawai people still adhere to their religious beliefs, called: arat sabulungan. The presence of the arat sabulungan belief is still very much felt in the Mentawai area, especially in Siberut. Most of the Mentawai people are Christians, because Christianity is matching in terms of their culture, namely, they like to eat pork and drink alcohol. The missionaries who came to preach to the Mentawai with sufficient capital and a decent salary. This is what hinders da'wah in the Mentawai. That is described as:

1. The distance between islands is far enough;

2. There is an insufficient fund for the preacher;

3. Most of the Muslim can't practice their prayers well;

4. Nurturing a pig is an honorable deed, which will be used in the party;

5. Women don't have rights, as for themself, family, or property;

6. Mentawai's Muslim still eating pork.

Islamization in Mentawai occurred because the Mentawai people became converts on their own consciousness, those who asked to be Islamized. Moreover, the Mentawai people accept Islam peacefully. There is no resistance from the community. Da'wah in Mentawai is full of hard struggles in accordance with the harsh Mentawai natural conditions as well. Most of the Mentawai Islands are still land areas covered by forests and some are in the form of oceans. Obstacles and not many preachers who are able to survive in broadcasting Islam. Funds for da'wah are often an obstacle. Some preachers claim that the preaching of Islam struggles among the waves of the Indonesian Ocean, for hours on a boat or small dipper to travel to do da'wah. ${ }^{11}$

There are at least six reasons why da'i want to preach in the Mentawai Islands, they are:

1. Da'wah ilallah;

2. A Message of the struggle of Minangkabau's preachers;

11 Abidin, "Pendakwak Di Mentawai, Wawancara Pribadi.” 
3. Mentawai is part of West Sumatra, if it is left behind, there will be a possibility that other people can take it, as evidenced by the large number of Mentawai people who are Muslim;

4. Da'wah program;

5. Mentawai Islands are a difficult area, should be a field of da'wah and devotion for the mujahid;

6. Bringing West Sumatra's program and bring up Nationalism.

Islamization in Mentawai proceeds peacefully, people convert to Islam without any coercion and no negotiation, but there must still be coaching activities. If there are no people, it is easy to change to their original religion. For converts to Islam, the most difficult thing is prayer. Funds for the Islamization of the Mentawai continue to come from both permanent and non-permanent donors. From the aid that came, Islamization in Mentawai was often used to buy and sell. Claiming to be for the benefit of converts, but used for self and group interests. ${ }^{12}$

Islamization in Mentawai occurred for several reasons, they are:

1. Marriage or marriage factors, for example, Mentawai's men and women who want to marry Muslim men and women, must become muslim

2. Calls for da'wah that occurred in Mentawai for non-Muslims 83\% while for Muslims 17\%

3. The number of Mentawai youth who study and conduct education outside the Mentawai area, causing them to change religion due to environmental factors.

Islamization in Mentawai proceeds in three steps, they are:

1. A call from the heart, starting with many guests who come and stay in the Mentawai area

12 Delfi, "Sipuisilam Dalam Selimut Arat Sabulungan Penganut Islam Mentawai Di Siberut.”
2. The occurrence of mixed marriages between non-Muslim men in Mentawai and vice versa.

3. The influence of the educational, whether in the Mentawai area or outside.

Islamization in Mentawai went peacefully. People converted to Islam without any coercion from certain parties. However, converts in Mentawai really need guidance, if there is no community development it is very easy to move to their original religion. Because the characteristics of the Mentawai people are very easy to feel comfortable with a certain religion, such as getting help, they can easily move.

Obstacles in Islam are growing in the Mentawai because Islam has many rules, such as praying five times, must be clean, regulated in Islam, and may not eat pork. Meanwhile, the Mentawai people like to eat pork, and in performing worship, it is not necessary to clean, which is essential. Terms of women's clothing season ${ }^{13}$ are:

1. Cover the whole body, even though there are differences of opinion regarding the hands and face

2. Do not let clothes become self-adornment

3. Wearing covered attire

4. Wearing loose attire so that it does not show the curves of the body

5. Do not wear flashy clothes

6. Do not wear clothes that resemble men and disbelievers.

7. Do not wear flashy clothes.

After government policy SK NO. 167/P.M/1954 was enforced in Mentawai, then three meetings were held. ${ }^{14}$ The development of the three religions recognized by the government (Protestantism, Catholicism, and Islam) is only Protestantism and Catholicism which is growing rapidly while Islam is not overgrowing when

13 Bahrun Ali Murtopo, "Etika Berpakaian Dalam Islam: Tinjauan Busana Wanita Sesuai Ketentuan Islam," Tajdid 1, no. 2 (2017): 243-251.

${ }^{14}$ Kebijakan SK NO, "Kebijakan Pemerintah SK No. 167/P.M," 1954. 
compared to the two religions, this is because these two religions can enter and adapt. with Mentawai culture. All the original rituals held by the community are held in the format of the Catholic religion, such as Christmas and New Year's Punden. Unlike the religion of Islam, not many members of the community who adhere to these religions. But especially the Baha'i religion which spread in 1950 still has many followers, even though the government has banned it. In its development the Baha'is have built a school building on the island of Siberut. ${ }^{15}$

At present, many Islamic organizations are trying to spread their influence on the island of Siberut. Even the Ministry of Social Affairs in its projects such as the resettlement project always makes plans for the construction of prayer rooms in its blueprints. ${ }^{16}$ Islam has more influence on the people who live on the shores of the coast or the capital of the sub-district, where. More often in contact with Minangkabau people, who are predominantly Muslim, but even there are not many. The majority of the religions adopted by the Mentawai people are Protestantism, followed by Catholicism, while Islam and Bahai are the minority religions. Even so, most people have original beliefs that are hereditary and until now this belief can be said to be an inherent tool. This belief lives in society even though they adhere to the divine religions mentioned above. ${ }^{17}$

The development of Islam in Mentawai experienced a setback due to lack of care and mental development, so they easily converted to a religion that could provide them with food to meet their daily needs and other assistance. This can be seen clearly, where Catholic missionaries easily get Catholics, by providing this material

15 Putri Citra Hati, "Dakwah Pada Masyarakat Minangkabau: Studi Kasus Pada Kaum Padri," Islamic Communication Journal 3, no. 1 (2018): 105-120.

16 Rita Erlinda et al., "Kearifan Lokal Dalam Wacana Dakwah," n.d.

17 Hilman Latief, "Islamic Charities and Dakwah Movements in a Muslim Minority Island: The Experience of Nissan Muslims," Journal of Indonesian Islam 6, no. 2 (2012): 221-244. assistance, people can even claim to be Protestants who have been in the Protestant faith for years. In fact, it is easy to find people who are considered strong in their beliefs, leaving their beliefs if they are given material assistance.

This religious conversion more or less caused competition among missionaries from the Protestant, Catholic, and Islamic religions. As an example of this competition where Protestant Christians are not happy with the actions of the Catholic mission because they preach or work in places where the population is already Protestant. ${ }^{18}$ Likewise, the situation of Islamic da'wah can also provide material assistance which they directly obtain, they will also convert to Islam in droves. The existence of competition among missionaries of these three religions will one day have an unfavorable impact on the development of the Mentawai people.

On the other hand, if we review it, we will also see that the Mentawai population (native people) in general, in carrying out a religion, is difficult to become a devout follower. In the current situation, the Protestant that has long developed in Mentawai over seventy years ago. For Islam, which has also taken a long time to develop, has become a role model for some Mentawai residents. Some of their charitable movements are seen as a manifesto of the beliefs they profess, if we look at religious buildings in Mentawai such as mosques, surau and churches or medical houses and so on, all of which are expecting help from outside. In upholding religion, they always expect a helping hand from outsiders. This religious attitude is relatively simultaneous from the followers of the

${ }^{18}$ Irman Irman, "Dinamika Kehidupan Mualaf Dan Dakwah Pendekatan Konseling Islam Di Kabupaten Kepulauan Mentawai Sumatera Barat," in Proceding AICIS XII Kemenag RI, 2012, 1150-1164. 
three major religions of Islam, Catholicism and Protestantism in Mentawai ${ }^{19}$

The spread of Islam also affects the social life of the community, the touches that occur are usually related to religious counseling, social assistance, although contact with Islam has experienced many obstacles which are generally caused by wide differences with community customs, the influence of Islamic influences can also affect the social life of the community. Enter into part of the community, especially those living in resettlement. ${ }^{20}$

The introduction of religions from outside, although outwardly acceptable and embraced by the community, but in terms of belief still adheres to the old system, so that old habits are still very much needed, kerey ${ }^{21}$ as an intermediary medium between the real world and belief plays a significant role in society, especially in terms of healing diseases suffered by individuals in society. The original beliefs that were initially trying to be erased through religion from outside will play a role again when the religions from outside are unable to overcome the problems that arise in society.

\section{ISLAMIZATION NEGOTIATION PATTERN IN MENTAWAI}

The negotiation pattern in question is synchronization with the factors that bind the Mentawai people who embrace Islam. These factors are caused by marriage, education, selfawareness and poverty. This fact is in the theories of Islamization put forward by experts.

\section{Marriage Pattern}

Mentawai's people have been used to have social contact with Muslims (immigrant).

19 Rudito, Masyarakat Dan Kebudayaan Suku Bangsa Mentawai (Padang: Laboratorium Antropologi Mentawai Fak. Ilmu Sosial dan Ilmu Politik Universitas Andalas, 1999).

20 Masoed Abidin, "Islam Dalam Pelukan Muhtadin Mentawai, 30 Tahun Perjalanan Dakwah Ilallah, Mentawai Menggapai Cahaya Iman," Dewan Dakwah Islamiyah Indonesia, 1997.

21 Alwi Alatas, "Penyebaran Islam Di Nusantara," Alam Islami Category, n.d.
This condition, not to mention, causes marriage between people. If Mentawai women are nonMuslims and men are Muslim immigrants, women must first become converts. And vice versa, if a non-Muslim Mentawai man wants to marry a Muslim woman, then the man must first take the shahada.

The Islamization of this marriage pattern is also by the findings of experts. Many Muslim traders who stay do not necessarily bring a family, so they then marry the natives. ${ }^{22}$ Merchants gradually began to settle either temporarily or permanently. Gradually these merchants formed a village known as Pekojan. The woman who will be married before has converted to Islam, thus forming a Muslim family. The number is gradually increasing so that an Islamic society is created. $^{23}$

This Islamization channel is very effective to do with Islamic merchants with the children of the nobility or the King. This marriage will accelerate the process of Islamization because the socio-political influence of the nobles and kings has a considerable influence in society. At a later stage, some of these traders started to form families by marrying local residents. Like the marriage between Raden Rahmat (Sunan Ampel) and Nyai Manila. ${ }^{24}$ The existence of this kind of process in the spread of Islam, so that the spread of Islam runs smoothly, because the result of marriage will form a Muslim family.

The issue of marriage in Islam is perfectly regulated in the Qur'an Surah AR-Rum (30:21): "And among the signs of His power is that He has created for you wives of your own kind, so that you may tend to

22 Rosita Baiti and Abdur Razzaq, "Teori Dan Proses Islamisasi Di Indonesia," Wardah 15, no. 2 (2014): 133-145.

23 Mitra Zalman, "Dampak Kebijakan Pemerintah SK N0. 167/PM/1954 Terhadap Perkembangan Islam Di Mentawai" (Fakultas Adab \& Humaniora UIN Syarif Hidayatullah. Badan Pusat Statistik Kepulauan Mentawai Tahun, 2020).

24 N Hamiyatun, "Peranan Sunan Ampel Dalam Dakwah Islam Dan Pembentukan Masyarakat Muslim Nusantara Di Ampel Denta," Dakwatuna: Jurnal Dakwah Dan Komunikasi Islam 5, no. 1 (2019): 38-57. 
and find peace in them, and He has created between you love and compassion. Verily in that there are indeed signs for a people who think. (Qs.AR-Rum 30:21)

Marriage in Islam is one of the sunnah, human being will gain the benefit, such as: Following the commands of Allah SWT., following the sunnah of Rasulullah and see him as the role model of life, eliminate lust and to lower the gaze and maintain chastity and maintain honor for both men and women, vanquish the misdeed, to grow a family that will continue the teaching of Muhammad SAW., Getting reward from doing halal relationship.

\section{Educational Pattern}

Mentawai children have attended many schools outside the Mentawai, such as Padang, Bukittinggi or Pariaman. They live in a boarding house with a Muslim family, that's when converting becomes an option. But the problem is that after returning to the family, he becomes an apostate. This happens because of the lack of guidance for converts. Education is a channel of Islamization in Indonesia that many of the missionaries have prepared cadres through education by establishing pesantren for students. From these students, the teachings of Islam will be socialized amid of society. ${ }^{25}$ In this boarding school the scholars prepare and develop Islam in all corners of Indonesia. A santri who has completed his education will return to their respective areas and become a religious teacher and religious leader.

The Mentawai people who were successfully "persuaded" to become Muslims were given scholarships to study Islam in Tanah Tepi, such as in Padang Panjang, Bukittinggi, Pariaman and Padang. The Mentawai students who have received religious knowledge are then sent back to the villages in Mentawai to teach the knowledge they have gained on the mainland of

25 Sidarta Pujiraharjo and Bambang Rudito, "Magi Sebagai Acuan Identitas Orang Mentawai Dalam Hubungan Antar Suku Bangsa," Jurnal Antropologi Fisip Unand, 2014.
Sumatra to people in Mentawai who have not or have just embraced Islam. Mentawai. ${ }^{26}$

\section{Self-Consciousness Pattern}

The entry of Islam is due to selfawareness, which will be more lasting than the factors of marriage and education. Usually these converts have a high desire to study Islam. And it is not easy to be an apostate either. Benefits of self-awareness ${ }^{27}$ are:

a. Self-awareness is the control of life. In this context, what is most important is a believer who can know that he is a very precious creation of God and does not see himself as like other animals who have basic needs to be satisfied and fought for;

b. Recognize how the characteristics of nature are explicit that allow people to see who they are with;

c. Knowing the spiritual aspect. Spirituality is not only influenced by human actions, but also by human ideas;

d. Understanding that the creator of the universe, including humans, is not a coincidence. In understanding its benefits, the mechanism of natural human processes that are always looking for reasons for their existence. Through self-awareness, contemplation and the purpose of creation, people will realize that each person is unique (different from one another);

e. Humans get great help in appreciating the elements of truth and critical awareness of the process of spiritual development and purification.

\section{Poverty Factors}

They need moral support for their lives. Life in the Mentawai is notoriously harsh. People generally live their life by hunting, entering the

${ }^{26}$ Delfi, "Sipuisilam Dalam Selimut Arat Sabulungan Penganut Islam Mentawai Di Siberut."

27 M.Quraish Shihab, Membumikan Alquran: Fungsi Dan Peran Wahyu Dalam Kehidupan Masyarakat (Bandung: Mizan, 2001). 
forest, leaving the forest to fulfill their daily needs. The natural wealth owned by the Mentawai does not necessarily make the population free from poverty. In fact, many are found in special orphanages for Mentawai children in Padang, non-Muslim parents in Mentawai who put their children in orphanages in Padang and let their children embrace Islam, for the sake of their children's future education. The reason children are put on the beach is to be the responsibility of the orphanage.

Islam views that poverty as something that can harm morals and logical thought. Islam also considers it a disaster and a disaster that should seek protection from Allah SWT for the evil hidden in it. If this poverty continues to run rampant, then this poverty will make you forget the existence of Allah SWT, who explains how dangerous poverty is, even poverty can lead to kufr. This is as contained in the hadith narrated by "From Anas bin Malik R.A Rasulullah SAW said: Poverty approaches disbelief" (HR. Abu Dawud).

Unbelief and disbelief have a very strong relationship, because disbelief is a step towards disbelief. A poor person, in general, will harbor malice towards people who are capable and rich. Envy and envy will be able to eliminate goodness. And they began to grow humiliation in their hearts, when they began to make every effort to achieve the goal of their envy. This perfection can nullify his religion and also causes disapproval of destiny, which makes criticizing his sustenance without realizing it will denounce the sustenance that has come to him. Although all are not yet included in disbelief, but it is a step to achieve disbelief itself.

\section{CONCLUSION}

Islamization in Mentawai was peaceful, there was no significant resistance. It is theoretically understood that coastal areas are more receptive to renewal. Catholic Christianity, Protestantism and Islam in the Mentawai can coexist, respect each other, and respect each other. The development of Islamization in Mentawai is still very low, the number of preachers who preach in terms of numbers is still lacking, including funds that do not support it. Most of the Mentawai converts do not yet understand Islam well, so they easily convert to their original religion. The Islamization that took place in the Mentawai did not necessarily keep converts away from the habit of eating pork, because for them pork was used as a standard of prestige in a family. It is essential because pigs determine Mentawai people's social status.

\section{BIBLIOGRAPHY}

Abidin, Buya Mas'ud. "Pendakwak Di Mentawai, Wawancara Pribadi," n.d.

Abidin, Masoed. "Islam Dalam Pelukan Muhtadin Mentawai, 30 Tahun Perjalanan Dakwah Ilallah, Mentawai Menggapai Cahaya Iman." Dewan Dakwah Islamiyah Indonesia, 1997.

Alatas, Alwi. "Penyebaran Islam Di Nusantara." Alam Islami Category, n.d.

Azra, Azyumardi. "Islamisasi Jawa." Studia Islamika 20, no. 1 (2013).

"Badan Pusat Statistik Kepulauan Mentawai," 2020.

Baiti, Rosita, and Abdur Razzaq. "Teori Dan Proses Islamisasi Di Indonesia." Wardah 15, no. 2 (2014): 133-145.

Bambang, Rudito. "Masyarakat Dan Kebudayaan Suku Bangsa Mentawai." Fisip Universitas Andalas, 1999.

Delfi, Maskota. "Sipuisilam Dalam Selimut Arat Sabulungan Penganut Islam Mentawai Di Siberut." Al-Ulum 12, no. 1 (2012): 1-34.

Devi, Silvia. "Adaptasi Masyarakat Di Tuapejat Kabupaten Kepulauan Mentawai Provinsi Sumatera Barat." Jurnal Penelitian Sejarah Dan Budaya 3, no. 2 (2017): 871-893.

Erlinda, Rita, Epic Andra, Wekke, and Ismail Suardi. "Kearifan Lokal Dalam Wacana Dakwah," n.d.

Hamiyatun, N. "Peranan Sunan Ampel Dalam Dakwah Islam Dan Pembentukan 
Masyarakat Muslim Nusantara Di Ampel Denta." Dakwatuna: Jurnal Dakwah Dan Komunikasi Islam 5, no. 1 (2019): 38-57.

Hati, Putri Citra. "Dakwah Pada Masyarakat Minangkabau: Studi Kasus Pada Kaum Padri." Islamic Communication Journal 3, no. 1 (2018): 105-120.

Irman, Irman. "Dinamika Kehidupan Mualaf Dan Dakwah Pendekatan Konseling Islam Di Kabupaten Kepulauan Mentawai Sumatera Barat." In Proceding AICIS XII Kemenag RI, 1150-1164, 2012.

Latief, Hilman. "Islamic Charities and Dakwah Movements in a Muslim Minority Island: The Experience of Nissan Muslims." Journal of Indonesian Islam 6, no. 2 (2012): 221-244.

Murtopo, Bahrun Ali. "Etika Berpakaian Dalam Islam: Tinjauan Busana Wanita Sesuai Ketentuan Islam.” Tajdid 1, no. 2 (2017): 243-251.

Naim, Mochtar. "Kehidupan Agama Di Mentawai" dalam Majalah Bulanan Mimbar Ulama, No. 8 Tahun I Februari" 8 (1977): 35 .

Pujiraharjo, Sidarta, and Bambang Rudito. "Magi Sebagai Acuan Identitas Orang Mentawai Dalam Hubungan Antar Suku Bangsa."
Jurnal Antropologi Fisip Unand, 2014.

Rosyani, Ika. "Kehidupan Arat Sabulungan Dalam Masyarakat Tradisional Mentawai."

Diss. Universitas Pendidikan Indonesia, 2013.

Rudito. Masyarakat Dan Kebudayaan Suku Bangsa Mentawai. Padang: Laboratorium Antropologi Mentawai Fak. Ilmu Sosial dan Ilmu Politik Universitas Andalas, 1999.

Shihab, M.Quraish. Membumikan Alquran: Fungsi Dan Peran Wabyu Dalam Kebidupan Masyarakat. Bandung: Mizan, 2001.

SK NO, Kebijakan. "Kebijakan Pemerintah SK No. 167/P.M,” 1954.

Sugiyono, Sugiyono. Metode Penelitian Kuantitatif Dan Kualitatif Dan R\&D, 2010.

Syafrizal, Achmad. "Sejarah Islam Nusantara." Islamuna: Jurnal Studi Islam 2, no. 2 (2015): 235-253.

“UU RI No. 49," 1999.

Zalman, Mitra. "Dampak Kebijakan Pemerintah SK No. 167/PM/1954 Terhadap Perkembangan Islam Di Mentawai." Fakultas Adab \& Humaniora UIN Syarif Hidayatullah. Badan Pusat Statistik Kepulauan Mentawai Tahun, 2020. 